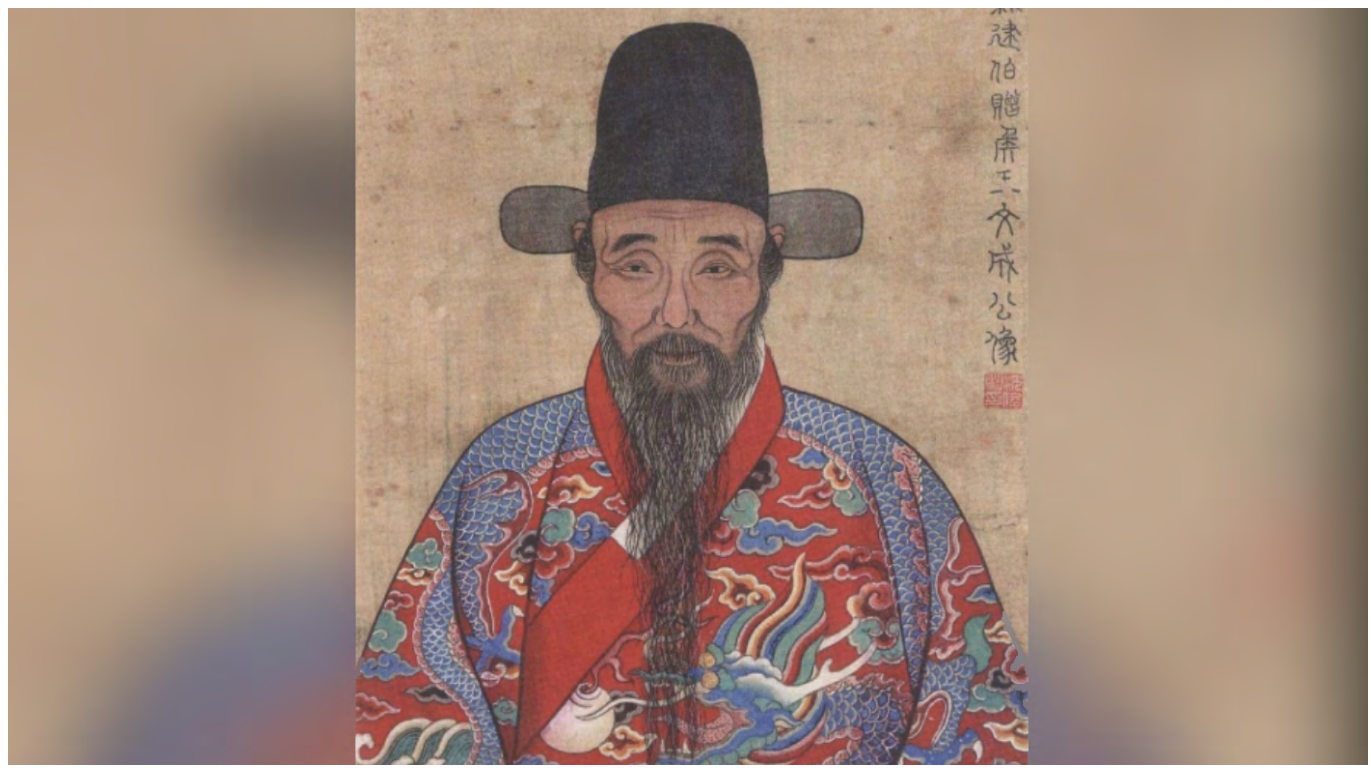

Wang Yangming. PC: Wikipedia, Public Domain.

\title{
The Trouble with Wang Yangming
}

\section{George L. ISRAEL}

The revered Confucian Wang Yangming has received much attention in recent years, not only because his compelling life story and philosophy deservedly attract it, but also because President Xi Jinping has openly expressed admiration for him. Building on the foundation of his grassroots popularity and historical and philosophical significance, the government of China has actively encouraged learning from the Ming Dynasty scholar-official. However, the political implications of his tenets and conduct as a Ming official have long been the subject of heated debate, one that remains relevant today. This essay reviews the revival of Yangmingism in China and explores the meaning of it.

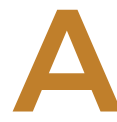
s many have observed, China's government has been touting Wang Yangming (14721529) and his School of Mind. President Xi Jinping has expressed a certain fondness for the famed Ming Dynasty (1368-1644) Confucian and scholar-official, even claiming that 'Wang Yangming's philosophy of mind truly is the quintessence of China's traditional culture; it is also one of the starting points for boosting the cultural self-confidence of Chinese people' (Li 2017). Several years ago, in an article published in the journal Philosophy East and West, I documented the history of this revival-that is, the burgeoning scholarship, historical restoration, monument construction, formation of study societies, and publication of educational materials for $\mathrm{K}-12$ students and training manuals for government employees (Israel 2016). The revival pre-dated the Xi era and was part and parcel of broader government support 
for and patronage of China's Confucian tradition (Page 2015), the purposes of which included supporting scholarship, placing Confucianism in the service of political goals and legitimation, instilling morality, and offering meaning at a time when modern ideologies had failed to do so, and promoting the globalisation of knowledge about Chinese history and philosophy (for its own sake, and as a form of soft power).

If anything, though, the pace has picked up in recent years. So notable was the Wang Yangming 'fever' and the robust funding driving it that international news organisations took note and reported it. Ian Johnson, a scholar and writer at The New York Times, penned a piece in 2017 with the apt title 'Forget Marx and Mao: Chinese City Honors Once-Banned Confucian'. He wrote:

\section{Restoring a sense of public morality has been a policy goal of Mr. Xi, who is set to be reap- pointed as Communist Party leader at the party's 19th congress starting Wednesday. In his efforts to address the country's spiritual shortcomings, Mr. Xi has spoken favorably of Confucius, praised Buddhism and presided over a revival of traditional religious prac- tices that were once condemned as supersti- tious. But he has seemed most comfortable praising the life and works of Wang Yangming. (Johnson 2017)}

Such praise makes sense. Wang has long been revered in East Asia, where he has enjoyed a certain grassroots popularity and was central to the Confucian projects of some of the most important twentieth-century Chinese philosophers, such as Mou Zongsan and Tang Junyi. They maintained that he had tapped into the very source of the universalistic spiritual dimensions of this great tradition. Wang's life story is also compelling, and many of the things he wrote and said provide moving testimony of the philosophical insights of a profoundly wise and deeply moral person. He deserves praise, admiration, and study, as well as to belong among the ranks of the world's great philosophers.

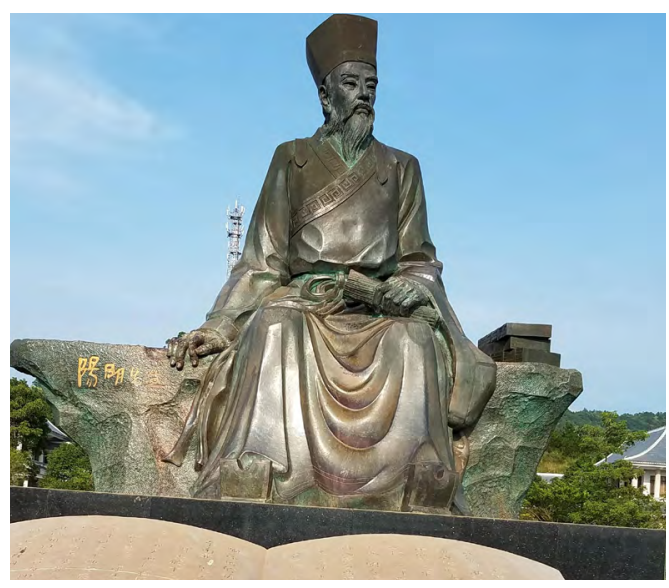

A statue of Wang Yangming and the museum devoted to him in Heping, Guangdong. PC: George L. Israel.

\section{Conflicting Scholarly Interpretations}

That said, prominent Chinese intellectuals such as Yu Yingshi (2014) have expressed their concern that should an authoritarian regime promote Confucianism, that may spell trouble for the tradition, insofar as it resuscitates it in its oppressive institutional forms. With respect to Wang Yangming, while academics in China might welcome the breathing space given to them by policy that supports pure scholarship and affords them the opportunity to talk about an individual and a school of thought many regard as the pinnacle of the Confucian tradition, others have reminded us that Wang's ideas were once regarded as tools of oppression. During the Maoist years, for instance, Wang was generally condemned for the military campaigns he led against 'peasants' and 'ethnic minorities'. These made him an agent of class oppression, and his philosophy had only served to give theoretical justification for his actions.

Indeed, Wang never fared well in Marxist scholarship, and even after Reform and Opening Up (from the 1980s), when scholarly perspectives diversified, some academics maintained that his tenets lent themselves to deeper state intervention in the moral life, for the purpose of instilling obedience in a population living under autocratic 
despotism. On the one hand, the Ming Confucian's principal teaching of extending (or realising) our innate (or intuitive) knowledge of the good (zhi liangzhi, 致良知) locates the ultimate source of moral authority in the individual's mind/heart and that mind/heart's intrinsic ability to perceive tianli (天理)-a higher, transcendent, or cosmic pattern, law, or reason. Put simply, with this inner light, we are inherently capable of knowing right and wrong because we can access a deeper moral order. That places a great deal of power in the hands of the individual and his or her conscience and would seem to be implicitly challenging existing structures of authority.

According to this line of interpretation, Wang Yangming's philosophy is liberating, charging the individual with a dignity born of an innate potential for sagehood and independent capacity for moral self-determination, both of which are well suited to liberal political traditions (Wu 2014). The Ming Confucian was in fact speaking from a place quite apart from a materialist ideology or the constraints imposed by socioculturally determined relations of power. He was speaking to the original conditionthe very essence or intrinsic reality-of the human mind and heart, where Heaven's pattern (or law) discloses moral knowledge to those possessing the clarity necessary to perceive it. Presumably, that is a place located beyond the reach of state interventions and even history. In fact, much of what Wang has to say about this only became clear to him after he had been treated very badly by the Ming emperor and his court.

On the other hand, Wang Yangming also appeared to believe that extending our good knowledge would serve to confirm the verity of a particular set of social norms or, more generally, what the philosopher Charles Taylor (2004: 23) refers to as a 'social imaginary': 'the way people imagine their social existence, how they fit together, how things go on between them and their fellows, the expectations that are normally met, and the deeper normative notions and images that underlie these expectations.' The renowned Sinologist William Theodore de Bary (1970: 151-52) wrote:
Wang Yangming seems to have assumed that the traditional Confucian relationships would remain intact. Innate knowledge of the good would only confirm them, revivify them with the spontaneity of freely given assent, and assure them of selfless commitment on the part of the individual.

He observed:

[F]or the most part his [Wang's] understanding of innate knowledge of the good was based on the assumption of a common moral nature in all mankind. Indeed, its common character was almost Wang's fundamental article of faith; individual differences were for him of secondary importance. (de Bary 1970: 151)

Similarly, David Nivison asserted that although Wang rejected the idea that moral knowledge could be mastered in advance through learned study and, rather, emphasised a kind of innate moral sense naturally responsive to any situation, he insisted that 'in a particular problem-situation, any morally perfected person would "hear" the voice of inner knowing in essentially the same way' as other morally upright people (Nivison 1996: 224-25).

Oddly enough, the earlier Marxist scholarship and the extent to which Wang Yangming's 'voice of inner knowing' might serve to validate existing power structures are the reasons dissident human rights activists, such as Yu Jie (2018), propose for Wang being touted where he was once condemned. A civilising discourse amenable to authoritarian appropriation as well as colonial projects lurks behind his thought and actions. Dimensions of Wang Yangming's own actions as a servant of the state reveal that his sense of right and wrong remained embedded in what the modern New Confucian Lin Anwu critically labels an imperial-style Confucianism-that is, a traditional Confucianism that evolved from natural bonds of consanguinity, moral bonds of human character, and political bonds of domination, and which was suited to a peasant economy, a lineage-based society, and an autocratic political system (Lin 
2011: 356-57). Insofar as Wang's traditionalism served to reinforce the last, by offering theoretical justification for uncritical affirmation of these bonds, his philosophy could lend itself to a modern ideological appropriation by a centralising authority claiming to act in the best interests of family, society, and nation.

\section{Appropriating Yangmingism Today}

However, such readings will remain subject to historical scrutiny, which is one reason contemporary Wang Yangming-ism has created a lively discursive space where contesting narratives thrive. Returning to China and events pertaining to Wang Yangming today, a few things stand out among the readily accessible information. One is the unveiling of monuments, such as giant statues, along with the construction of museums. That has happened wherever the Ming scholar has left traces, including his hometowns of Yuyao and Shaoxing in Zhejiang Province; in Xiuwen County, Guizhou Province, where he experienced a kind of spiritual and intellectual enlightenment; and in county seats established by him in the wake of military campaigns conducted to suppress outlawry and internecine strife. Those seats include Fujian Province's Pinghe County, Jiangxi Province's Chongyi County, and Guangdong Province's Heping County. Much funding has been disbursed for this construction, and it has made for some interesting work featuring local history. Promoting tourism is also a goal here, and indeed all these places are quite charming, and well worth a visit.

Another reason is passing statements made by President Xi Jinping. Xi's patronage of Confucianism more generally is well known (Jin 2014). Close observers in China have noted when he mentions Wang as well as his allusions to Wang's philosophical tenets (especially the 'unity of knowledge and action'). Occasionally, they post something online documenting what was said where. These posts often begin by highlighting what Xi had once asserted about the significance of Wang
Yangming's learning of mind-that it is the essence of China's traditional culture and is essential for enhancing cultural confidence (see, for instance, Li 2017). Thus, Xi has linked Wang to his goals for 'national rejuvenation' (CGTN 2021). That is why businesses like the Yangming Philosophy Academy (知行合一阳明教育研究院, literally, 'The Unity of Knowledge and Action Yangming Education Research Institute') have jumped on board, offering training sessions on how Wang Yangming's ideas can improve business practices and bring success; why Wang Yangming conferences bringing people together from diverse sectors of society are routinely convened; and why bookstores are full of trade publications that bring his life and philosophy to broader audiences. In the simplest of senses, the revered Ming Confucian gives heart to what are otherwise heteronomous pursuits.

For this reason, differing historical interpretations of the Ming Confucian have become unusually relevant. For example, in China, it appears to be widely believed that Yangming-ism played a key role in the Meiji Restoration and Japan's successful modernisation-a modernisation that turned Japan into a dominant power in East Asia by the late nineteenth century. Yet the idea that Wang's thought provided intellectual resources for that process has been shown to be largely a construction of late-nineteenth and early twentieth-century Japanese intellectuals. They had found in him a resource for engendering nationalism, as Ogyū Shigehiro (2000) and Oleg Benesch (2009) have demonstrated.

Thus, while giving Wang Yangming a role in the projects of cultural pride and national rejuvenation surely has its merits, the definition of these goals and their manner of execution will also have the effect of bringing forward certain understandings of him and his School of Mind. That may have the unintended consequence of privileging one line of interpretation, while placing constraints on others, such as one that would stress the potentially universal reach of his humanism.

In 1527, Wang wrote a letter to his son while en route to Guangxi Province, where he had been charged with the task of quelling unrest among non-Chinese peoples native to southern China. He explained to him the crux of his teaching at 
this time, which, of course, concerned how we are to go about realising and extending to others our innate capacity to know right from wrong. This was Wang Yangming's famed doctrine of zhi liangzhi, as discussed above. Wang told his son:

\section{[W] hat I have taught all my life when discussing learning is only the three char- acters zhi liang zhi. The human heart is humaneness. Humaneness is the genuinely loving and compassionate dimension of the innate knowledge. Absent a genuinely loving and compassionate heart, there is no innate knowledge of the good that can be extended. (Wang 2012: vol. 2, juan 26, p. 818)}

Indeed, it is this fundamental moral knowledge that gives us the capacity to realise a vision of a humane unity (what the neo-Confucians call the 'one body or substance of humanity'). Wang Yangming's basic tenets speak to the capacity of all humans for an unbounded caring of universal reach. It is our humanity that forms of all things one body, one totality.

It is true that, for Wang, realising our innately virtuous capacities begins with extending love to those closest to us. By first loving our own father, we can understand loving others' fathers, and then all fathers, for example (Wang 2012: vol. 1, 7, p. 211). The same applies to others closest to us. Not unlike Stoic oikeiosis, circles of care begin with what is near and end with what is far (Yu 2017). Our genuine love and compassion, our humaneness, can be extended to others through concentric circles, from self to family to group to country, until the entire circle-Heaven, Earth, and the myriad things-is encompassed.

Of course, Wang Yangming's hopes for our moral capacities appear quite idealistic. It is difficult to extend our genuine love and compassion when everything about ourselves and the complexities of the world seem to work against us to constrict our reach. He was quite aware of this, and his writings can be rather pessimistic at times. He says that people are normally self-centred and hanker after recognition, status, and wealth. Their minds are like polluted water, whose natural clarity is difficult to restore. They find it easier to follow the morally corrupt and become so themselves rather than risk the ridicule, jealousy, and envy that being righteous seems to incur. In his assessment: 'The world has for long been swept over by a wave of degeneracy-how does it differ from someone who is terminally ill?' (Wang 2012: vol. 3, juan 21, p. 672).

Furthermore, let us imagine that someone has removed obstructions preventing awareness of this knowledge of right and wrong and hence become fully able to extend his or her humanity to the utmost. As such, moral action should take place quite effortlessly. According to Wang's tenet of the unity of knowledge and action, our innate knowledge, insofar as it is clear, becomes something like a guiding light available to us in any moment and under any circumstance, directing us down the right path, such that our moral life becomes spontaneous and natural.

Yet, as the world is fraught with moral complexity, how is such a unified moral life to align with it? Wang Yangming himself is something of a case study in this regard, especially the decisions he made as a Ming official. In fact, just after he penned the letter to his son, he carried out military campaigns against non-Chinese ethnic groups located in Guangxi Province. While some scholars see only political necessity at work (he did the best he could under the circumstances), others have argued the language he used to describe resistant peoples, and which served as justification for applying the military instrument and implementing policies designed to civilise and settle them under the Ming Empire, reveal contradictions, displaying a potentially oppressive facet of his philosophical discourse. Wang had placed his humanistic ideals in the service of a paternalistic civilising discourse and the colonising ends of the Ming state (Shin 2006).

This would seem to suggest that extending our good knowledge through concentric circles of care will rarely be easy, as we run up against social and political reality, insofar as those circles are usually not simply nested one within the other. Perhaps several overlapping or independent circles are nested within one larger one, but that larger one escapes the reach of any political entity. As such, it seems possible that our liangzhi and fundamental intuition of unity could find themselves tied to or 
contracted within one circle, making claims on behalf of it to the detriment of others. Our pre-existing assumptions about the nature of the social and political may have shaped what we assumed to be natural knowledge of right and wrong. In other words, concepts central to the Ming School of Mind, including liangzhi, the one body of humanity, and the unity of knowledge and action may lend themselves to appropriation.

In fact, Wang Yangming's tenets have been subject to reinterpretation in ways that reshape them to ends debatably true or alien to their original intent. A good example of this can be found in David Ownby and Timothy Cheek's introduction to Ownby's translation of an essay by Jiang Shigong. The Chinese edition was originally published in a journal in 2018 and intended as an authoritative statement of the new political orthodoxy under President Xi. The essay integrates traditional Chinese thought with communist theory, building 'on a flirtation between the New Left and New Confucians which has been underway for some time'. Ownby and Cheek write:

The text is littered with classical Confucian
expressions like 'original intention' 初心 which
liken the scholar's commitment to the Way
to the Communist's dedication to revolution.
Communism is presented as the equivalent
of the 'learning of the heart '心学,' one of the
Chinese names by which Neo-Confucianism
is known, linking Wang Yangming's 'innate
knowledge' 良知 to Maoist voluntarism in a
creative attempt to redefine communism as a
goal to be achieved by cultivating the proper
spirit rather than through class warfare. As
China moves forward, it also embraces its past;
what will flourish in the twenty-first century
and beyond is Chinese civilization. (Jiang 2018)

In other words, with respect to Wang Yangming's tenets, realising our innate knowledge of what counts as good is redefined within the framework of the values-the spirit-and goals of the Chinese Communist Party or, more generally, according to the horizon of the social imaginary as the Party would like to shape it and as it exists in Han Chinese society. One's sense of right and wrong will surely know that the goal of national rejuvenation is correct. The same would apply to Wang's theory of the unity of knowledge and action. Theoretical and practical knowledge will now be understood within the framework provided by Marxism-Leninism-Maoism and Xi Jinping Thought. With regards to practical action, this theory essentially supplants the role played by Heaven's pattern in Wang Yangming's philosophy. He had identified it with liangzhi, and thus as the ultimate source of authority. The source of authority now shifts from the transcendent and the inherent capacity of the individual's mind/heart to a state's modern ideology, or at least that ideology's interpretation of the nature of the guidance provided by this authority. Lastly, our fundamental ability to form one body with Heaven, Earth, and the myriad things-because it is natural to our mind and heart-potentially sees a slight contraction, bounding what is higher and inclusive with the desires, civilisational assumptions, social imaginary, and political aims of a particular people.

\section{Questions for Our Liangzhi}

These are just some of the ways and reasons Wang Yangming and his School of Mind have been appearing in China today. I have tried to explain and document this largely as an outside observer, in a detached, objective fashion. Others can draw their own conclusions and form their own judgements. Would it have been better had the Ming Confucian not been praised, and if such flirtation with the Ming School of Mind were set aside? I do not believe researchers in this area or admirers of Wang Yangming would think so. However, the Government of China might reflect on whether it is correctly extending, or realising, Wang Yangming's vision. Does it need to be disentangled from, or expanded beyond, the political discourse and social imaginary in which it is now embedded? These are questions worthy of further consideration. 
This text is taken from Made in China Journal: Volume 6, Issue 3, 2021, edited by Ivan Franceschini, Nicholas Loubere and Shui-yin Sharon Yam, published 2022 by ANU Press, The Australian National University, Canberra, Australia.

doi.org/10.22459/MIC.06.03.2021.05 